\title{
Blood concentration of carbon disulphide in "normal" subjects and in alcoholic subjects treated with disulfiram
}

\author{
F Brugnone, G Maranelli, S Zotti, I Zanella, P De Paris, S Caroldi, A Betta
}

\begin{abstract}
Assay of free and acid labile carbon disulphide (free and total $\mathrm{CS}_{2}$ respectively) in human blood was performed by gas chromatography/ spectrometry. The method used a large dynamic head space volume and a "cryogenic trap". Blood $\mathrm{CS}_{2}$ concentration was measured in 42 subjects not occupationally exposed to $\mathrm{CS}_{2}$ (group $A$ ) and in 11 alcoholic subjects (group B) treated with disulfiram. Free $\mathbf{C S}_{2}$ concentration showed a mean value of $261 \mathrm{ng} / 1$ in the 42 subjects in group $A$ and $9482 \mathrm{ng} / 1$ in eight subjects of group B. Total $\mathrm{CS}_{2}$ concentration was $897 \mathrm{ng} / 1$ and $40084 \mathrm{ng} / 1$ in groups $A$ and $B$ respectively. Differences between the groups were highly significant for concentrations of both free and total $\mathrm{CS}_{2}$. Total $\mathrm{CS}_{2}$ concentration was about four times as high as free $\mathrm{CS}_{2}$ concentration in both groups. A significant correlation was found between free and total $\mathrm{CS}_{2}$ concentration both in group $A$ and in group B. In the alcoholic subjects (group B), blood concentrations of both free and total $\mathrm{CS}_{2}$ were related to time of sampling after treatment with disulfiram.
\end{abstract}

Carbon disulphide $\left(\mathrm{CS}_{2}\right)$ is a natural, ubiquitous polluting agent derived from various natural sources such as volcanic activity and combustion of organic substances, from biological (particularly microbial) processes, and from industrial activity. ${ }^{1-5}$ It is widely known in occupational medicine because of the risk of serious toxic effects commonly identified in the past

Istituto di Medicina del Lavoro, Università di Verona, 37134 Verona, Italy

F Brugnone, G Maranelli

3* Divisione di Medicina, ULS 21, 35127 Padova, Italy

S Zotti, I Zanella

Istituto di Medicina del Lavoro, Università di Padova, 35127 Padova, Italy

S Caroldi, P De Paris

Servizio di Medicina del Lavoro di Trento, 38100

Trento, Italy

A Betta in the rubber, match, and viscose industries. This risk is now confined mainly to viscose production and to the exposure to $\mathrm{CS}_{2}$ deriving from the production and use of dithiocarbamates. 5 The difficulty of accurate assay of $\mathrm{CS}_{2}$ in biological fluids from subjects occupationally exposed to the substance ${ }^{6-8}$ is due not only to the analytical methods, but also to the chemical properties of $\mathrm{CS}_{2}$, which render it highly reactive with biological substrates. Research both in vitro and in vivo has shown that $\mathrm{CS}_{2}$ in blood and biological substrates is in part free and in part subject to acid labile binding with blood proteins and, in general, with nucleophilic substances containing $-\mathrm{SH},-\mathrm{NH}$, and $-\mathrm{OH}$ groups. ${ }^{9}$

This paper describes a method of assaying blood $\mathrm{CS}_{2}$ in subjects not occupationally exposed to $\mathrm{CS}_{2}$ and in subjects treated with the dithiocarbamate disulfiram (Antabuse).

Materials and methods

Carbon disulphide was assayed in the blood of 53 subjects subdivided into 42 "normal" subjects not occupationally exposed to $\mathrm{CS}_{2}$ and 11 alcoholic subjects treated with disulfiram (Antabuse).

As occurs with dithiocarbamates, disulfiram metabolism gives rise to $\mathrm{CS}_{2}$ production. Disulfiram was administered orally at a dosage of $200 \mathrm{mg} /$ day for 19-38 days to eight of the 11 alcoholic subjects. Blood was sampled in these eight subjects between two and 72 hours from the last administration of disulfiram. One single dose of $200 \mathrm{mg}$ of disulfiram was administered orally to the other three alcoholic subjects whose blood was sampled $0,1,2,4,6,12,24$, and 48 hours after the administration of disulfiram. Informed consent was obtained from all alcoholic subjects.

TREATMENT AND STORAGE OF BLOOD SAMPLES Blood samples $(5-10 \mathrm{ml})$, taken with a glass syringe (disposable syringes were not used to avoid release of $\mathrm{CS}_{2}$ from the rubber of the plunger), were placed in glass tubes containing two drops of $10 \%$ ethylenediaminetetracetate (EDTA) solution. The glass tube, filled to capacity to avoid any residual air 
bubbles between the blood surface and the tube cap, was closed with a pierceable screw on cap fitted with a teflon rubber ring seal (pyrex or sovirel tubes were adapted by us for this purpose). After stirring briefly to favour the anticoagulant effect of EDTA, the blood samples were stored at $4^{\circ} \mathrm{C}$ until use.

\section{DETERMINATION OF FREE AND BOUND CARBON DISULPHIDE (FREE $\mathrm{CS}_{2}$ AND TOTAL $\mathrm{CS}_{2}$ ) \\ Free $\mathrm{CS}_{2}$}

After shaking, $3 \mathrm{ml}$ of blood were drawn off through the cap of the tube into a glass syringe and injected into a $70 \mathrm{ml}$ glass bottle (Duran, Schott) closed with a pierceable screw on cap fitted with a teflon rubber ring seal $(2.5 \mathrm{~mm}$ thick) arranged by us. The bottle and blood was shaken in a rotating agitator at room temperature for one hour.

\section{DYNAMIC HEAD SPACE (STRIPPING)}

By passing two needles through the cap, the bottle was connected to the gas chromatography carrier circuit; the incoming needle passed just over but did not touch the surface of the blood sample, and the outgoing needle barely protruded beyond the inner surface of the screw cap. Connection between the glass container and the carrier circuit was established or interrupted by means of a valve. The carrier (flow rate about $20 \mathrm{ml} / \mathrm{min}$ ) was allowed to enter the glass container holding the sample, for exactly six minutes. Outgoing carrier entered a cryogenic trap, downstream from which (and before the gas chromatography column) was a splitter valve, to be left open throughout the stripping process.

Sample concentration-Carrier entering the container mixed with the volatile products that were released into the available head space and transported them to the cryogenic trap, made up of a $10 \mathrm{~cm}$ stainless steel tube with an internal diameter of $1 \mathrm{~mm}$ and a $U$ bend containing $3 \mathrm{mg}$ of Tenax in its central portion. Throughout the stripping process (six minutes), the trap remained immersed in an ethylene glycol bath at $-20^{\circ} \mathrm{C}$. When stripping was complete, with the splitter valve closed, the cryogenic trap was removed from the bath and heated for 2.5 seconds to $200-300^{\circ} \mathrm{C}$. Closure of the stripper (when stripping was finished and before heating the cryogenic trap) re-established the normal carrier flow rate of $0 \cdot 7-1 \cdot 0$ $\mathrm{ml} / \mathrm{min}$ within the gas chromatography column. Heating the trap allowed the products adsorbed by the Tenax to be released into the gas chromatography column for analysis and identification. Apart from the cryogenic trap, all the tubing, connections, and valves were maintained at $80^{\circ} \mathrm{C}$ to avoid condensation of solvent on the tube walls.

TOTAL $\mathrm{Cs}_{2}$

One $\mathrm{ml}$ of blood was drawn off in a glass syringe through the pierceable cap of the tube (after shaking) and injected into a $70 \mathrm{ml}$ glass container (identical to that described above) containing $2 \mathrm{ml} 1 \%$ hydrochloric acid solution in water. The sample was then placed in an oven at $100^{\circ} \mathrm{C}$ for one hour and, after cooling, the same procedure as for free $\mathrm{CS}_{2}$ was performed. Acid labile $\mathrm{CS}_{2}$ was freed by acid hydrolysis and was determined, together with the free $\mathrm{CS}_{2}$ blood concentration, as total (free plus bound) $\mathrm{CS}_{2}$. The real acid labile $\mathrm{CS}_{2}$ can be obtained by subtracting free (assayed separately) from total $\mathrm{CS}_{2}$.

GAS CHROMATOGRAPHY MASS SPECTROMETRY ANALYSIS A Hewlett Packard 5890 gas chromatograph with a silica capillary column of cross linked $5 \%$ phenyl methyl silicone $(0.17 \mu \mathrm{m}$ thick, $50 \mathrm{~m}$ long, $0.32 \mathrm{~mm}$ internal diameter) was used. The initial column temperature was maintained constant for five minutes and then programmed from $35^{\circ} \mathrm{C}$ to $100^{\circ} \mathrm{C}$ at $40^{\circ} \mathrm{C} /$ $\mathrm{min}$. The carrier was purified helium with a flow rate of $0.8 \mathrm{ml} / \mathrm{min}$. A Hewlett Packard 5970B selective detector (quadruple) was used for identification. Identification of $\mathrm{CS}_{2}$ was obtained from the gas chromatography retention time, comparison of $\mathrm{m} / \mathrm{z}$ 76 and 78 ions, and identification of their isotopic ratio (fig 1).

\section{Standards and calibration}

Blood samples $(20-30 \mathrm{ml})$ from "normal" people were drawn daily from the blood bank for each repetition of four to six points of the calibration curve. Before use the blood sample was stripped with a flow of helium and it was rejected if its background concentration of $\mathrm{CS}_{2}$ was more than twice that of double distilled water. The non-eliminable background value was subtracted from those of the standards. Calibration curves were prepared by adding scaled quantities of $\mathrm{CS}_{2}$.

Figure 2 shows the linearity of the calibration curve for the scaled concentrations from $390 \mathrm{ng} / \mathrm{l}$ to $22 \mu \mathrm{g} / 1$. One or more points on the line were repeated daily, together with the assay of the samples to be evaluated. The detection threshold for $\mathrm{CS}_{2}$ was 25 $\mathrm{ng} / \mathrm{l}$ and the coefficient of variation for all points was lower than $20 \%$. Standards of $\mathrm{CS}_{2}$ were prepared in $\mathrm{H}_{2} \mathrm{O}$ and homogenised by ultrasound treatment. To prepare the calibration curve, standards were injected into the head space of the glass container $(70 \mathrm{ml})$ containing $3 \mathrm{ml}$ of blood.

\section{STATISTICAL ANALYSES}

Non-parametric (Kruskal-Wallis test $(\mathrm{H})$ and Wilcoxon-Mann-Whitney test $(Z)$ ) and parametric (Student's $t$ test $(t)$ and analysis of variance (F)) tests were used to compare blood concentrations of $\mathrm{CS}_{2}$ between the individual groups. Spearman rank correlation coefficients $\left(r_{s}\right)$ and regression analyses were used for the correlations between free and total $\mathrm{CS}_{2}$ 


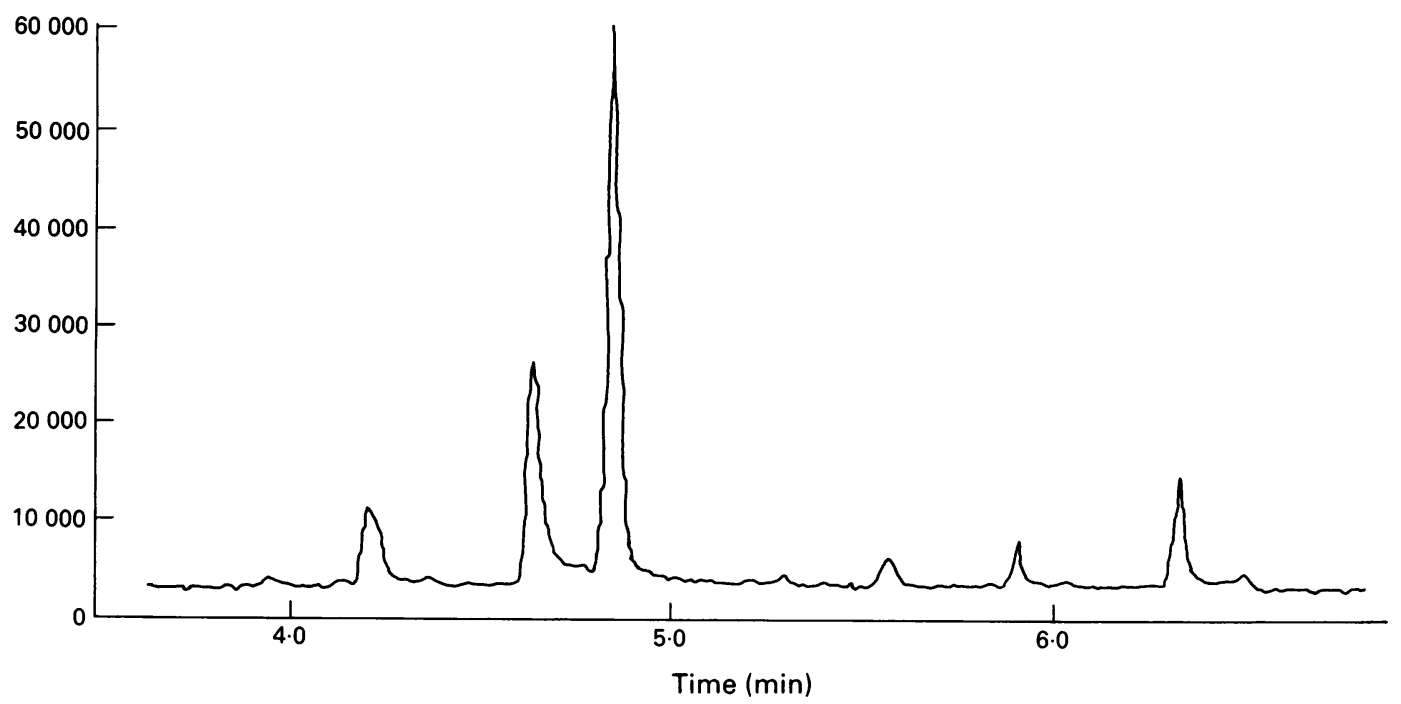

Ion $76.00 \mathrm{amu}$
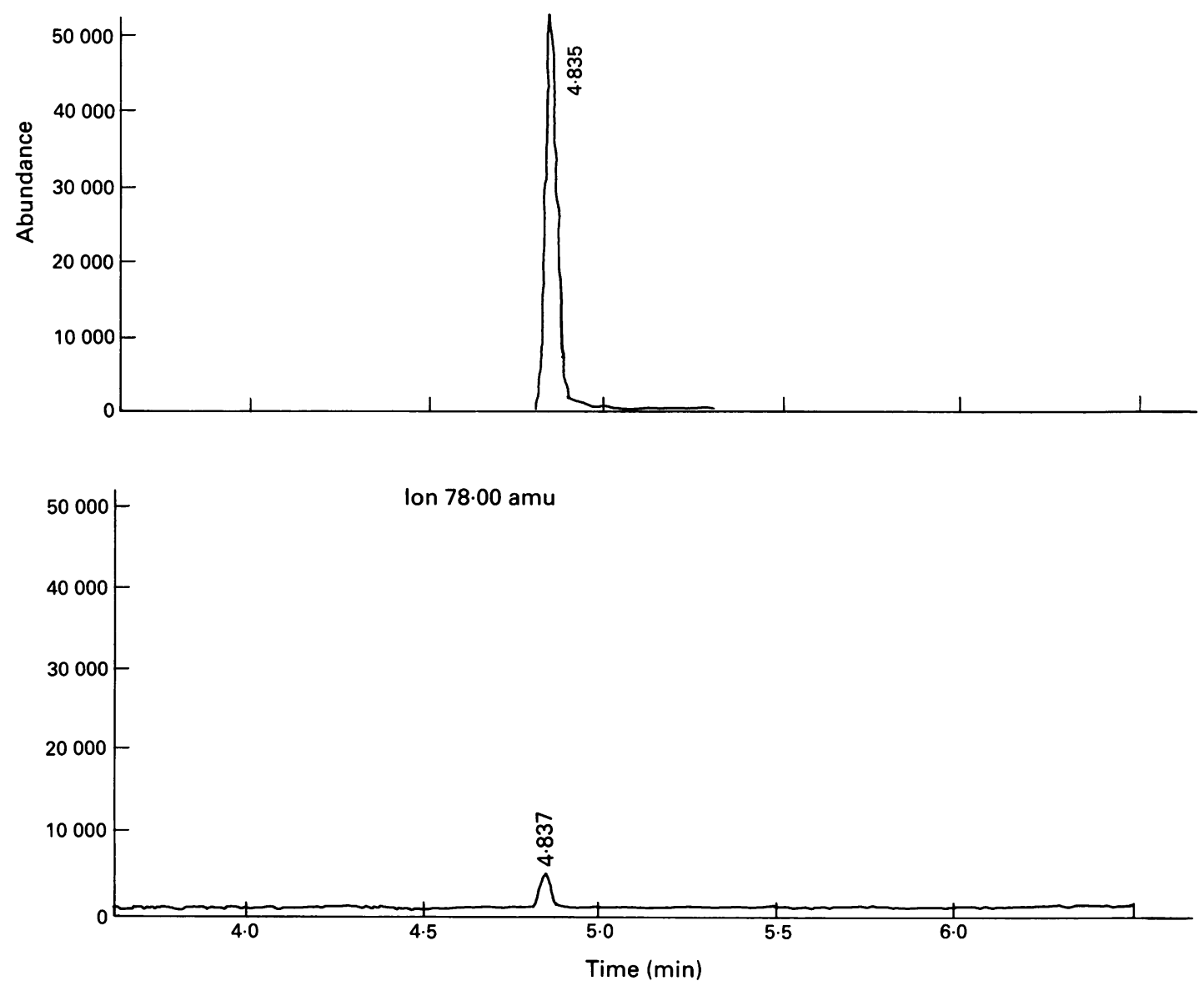

Figure 1 Gas chromatography/mass spectroscopic analysis of blood with identification of CS $S_{2}$ by retention time (4.83 minutes), and ions 76 and 78 amu. 


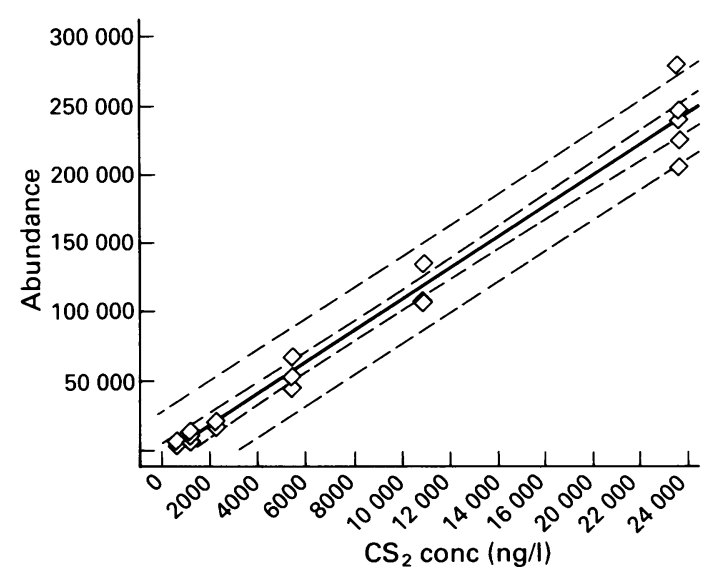

Figure 2 Calibration curve of $\mathrm{CS}_{2}$ (correlation coefficient $=0.99$ ).

concentration. A test was considered statistically significant with $\mathrm{p}<0.05$.

\section{Results}

Free $\mathrm{CS}_{2}$ concentration had a mean value of $261 \mathrm{ng} / 1$ in the 42 normal subjects (group A) and $9482 \mathrm{ng} / \mathrm{l}$ in the eight alcoholic subjects treated for 19-38 days with disulfiram (group B). Total $\mathrm{CS}_{2}$ concentrations were higher than those of free $\mathrm{CS}_{2}$, with values of 897 $\mathrm{ng} / 1$ and $40084 \mathrm{ng} / 1$ in groups $A$ and $B$ respectively. Differences between the two groups were highly significant for both free and total $\mathrm{CS}_{2}$ concentrations (table 1). Table 1 shows a similar total:free $\mathrm{CS}_{2}$ ratio in the 42 normal subjects (3.9) and in the eight alcoholic subjects treated with multiple doses of disulfiram (4.3). The difference between groups was not significant. Figure 3 shows the distribution of values for the ratio among 50 subjects (groups $A$ and B). Free $\mathrm{CS}_{2}$ showed a significant relation with total $\mathrm{CS}_{2}$ (table 2; fig 4), both within each group and overall. In the eight alcoholic subjects treated for 19-
38 days, the times at which blood samples were taken varied from two to 72 hours after the last dose of disulfiram. These subjects showed no significant relation between the total intake of disulfiram and the blood concentration of $\mathrm{CS}_{2}$, although blood $\mathrm{CS}_{2}$ concentration was inversely proportional to the interval between the last administration of disulfiram and the time at which the blood sample was taken. The few data reported in figures 5 and 6 suggest an exponential reduction in free and total (free + bound) blood $\mathrm{CS}_{2}$ concentration as the time to sampling increased. For group B, the mean blood half life of $\mathrm{CS}_{2}$ was 11 hours for free $\mathrm{CS}_{2}$ and seven hours for total $\mathrm{CS}_{2}$ in the first 24 hours after last administration of disulfiram, and 23 and 17 hours respectively in the 72 hour interval.

Figure 7 shows the blood variations of free and total $\mathrm{CS}_{2}$ in the three alcoholic subjects who were tested during the 48 hours after the administration of one single dose $(200 \mathrm{mg})$ of disulfiram. Free $\mathrm{CS}_{2}$ and total $\mathrm{CS}_{2}$ concentration increased in blood after administration of disulfiram and reached maximum concentrations after 12 and 24 hours respectively. Moreover, after 48 hours, free and total $\mathrm{CS}_{2}$ blood concentrations were still higher than those measured before administration of disulfiram (time zero).

\section{Discussion}

In experimental animals treated with $\mathrm{CS}_{2}$ at much higher doses than the concentrations absorbed during occupational exposure, free and bound $\mathrm{CS}_{2}$ are normally measured with ease in blood and other biological media by colorimetric methods. ${ }^{10-12}$ In human subjects the monitoring of occupational exposure to $\mathrm{CS}_{2}$ by its measurement in biological media has generally been considered unsuitable because of the poor reproducibility of the biological data. ${ }^{6-813}$ Recently, Campbell et $a l^{14}$ tried to measure free and acid labile $\mathrm{CS}_{2}$ concentrations in the blood of workers occupationally exposed to the substance in the rayon industry. The detectable limit for $\mathrm{CS}_{2}$

Table 1 Values for free (free $C S_{2}$ ), total (total $C S_{2}$ ) and ratio (total:free) of $C S_{2}$ concentration in blood of normal people (N) and alcoholic subjects ( Alc)

\begin{tabular}{|c|c|c|c|c|c|c|}
\hline \multirow[b]{2}{*}{ Group } & \multicolumn{2}{|c|}{ Free $C S_{2}(n g / l)$} & \multicolumn{2}{|c|}{ Total $C S_{2}(n g / l)$} & \multicolumn{2}{|c|}{$\begin{array}{l}\text { Ratio } \\
\text { Total } \mathrm{CS}_{2} \text { :free } \mathrm{CS}_{2}\end{array}$} \\
\hline & $N$ & Alc & $N$ & $A l c$ & $N$ & Alc \\
\hline $\begin{array}{l}\text { No of subjects } \\
\text { Mean } \\
\text { Median } \\
\text { Geometric mean } \\
\text { SD } \\
\text { SE } \\
\text { Minimum } \\
\text { Maximum }\end{array}$ & $\begin{array}{r}42 \\
261 \\
160 \\
195 \\
206 \\
32 \\
37 \\
758\end{array}$ & $\begin{array}{r}8 \\
9482 \\
9070 \\
4932 \\
9025 \\
3191 \\
595 \\
27055\end{array}$ & $\begin{array}{r}42 \\
897 \\
627 \\
665 \\
759 \\
117 \\
144 \\
3095\end{array}$ & $\begin{array}{r}8 \\
40084 \\
24273 \\
18484 \\
40768 \\
14414 \\
1448 \\
107130\end{array}$ & $\begin{array}{r}42 \\
3 \cdot 90 \\
3 \cdot 40 \\
3 \cdot 40 \\
2 \cdot 42 \\
0 \cdot 37 \\
1 \cdot 30 \\
12 \cdot 70\end{array}$ & $\begin{array}{l}8 \\
4 \cdot 30 \\
3 \cdot 40 \\
3 \cdot 70 \\
2.56 \\
0.90 \\
1 \cdot 60 \\
9 \cdot 60\end{array}$ \\
\hline
\end{tabular}

Free $\mathrm{CS}_{2} ; \mathrm{N}$ :Alc; $\mathrm{F}=47.9 ; \mathrm{p}<0.0001 ; \mathrm{H}=18.6 ; \mathrm{p}<0.0005 ; t=6.92 ; \mathrm{p}<0.0001 ; \mathrm{z}=4.31 ; \mathrm{p}<0.0005$

Total $\mathrm{CS}_{2}$; N:Alc; $\mathrm{F}=42.7 ; \mathrm{p}<0.0001 ; \mathrm{H}=18.1 ; \mathrm{p}<0.0005 ; t=6.52 ; \mathrm{p}<0.0001 ; \mathrm{z}=4.25 ; \mathrm{p}<0.0005$. 


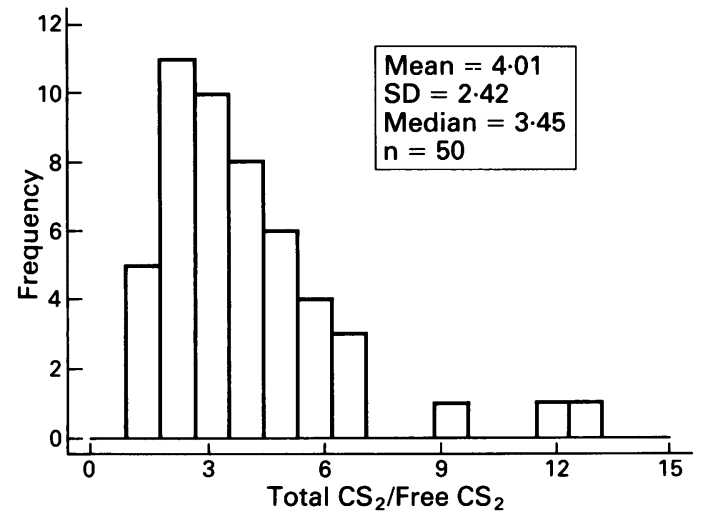

Figure 3 Distribution of the ratio values between total and free $C S_{2}$ concentrations (total $C S_{2}$ :free $C S_{2}$ ) in the blood of 42 "normal" and eight alcoholic subjects.

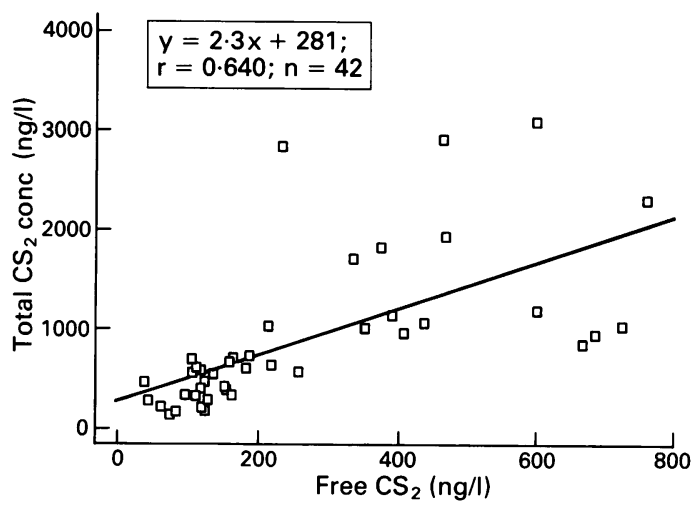

Figure 4 Correlation between free $\mathrm{CS}_{2}$ and total $\mathrm{CS}_{2}$ in "normal" subjects $(y=2.3 \times+281 ; n=42 ; r=0.640$; $\left.p<0.001 ; r_{s}=0.817 ; p<0.00001\right)$.

concentration in blood was $15 \mu \mathrm{g} / 1$. With this limit, determination of blood $\mathrm{CS}_{2}$ concentrations in control subjects and in workers tested before shift work was impossible. Only at the end of the shift were values of blood bound $\mathrm{CS}_{2}$ (332 (first workday) and $228 \mu \mathrm{g} / 1$ (fifth work day)) measurable. Our dynamic head space method for blood $\mathrm{CS}_{2}$ assay has two characteristic features: (1) a large head space volume $(70 \mathrm{ml})$ compared with the blood sample volume ( $3 \mathrm{ml}) ;(2)$ a cryogenic trap that makes it possible to concentrate $\mathrm{CS}_{2}$ after its aerodispersion in the large head space. The gas is first adsorbed in the cryogenic trap by the Tenax because of the low temperature, and is subsequently released when the trap is heated to $200-$

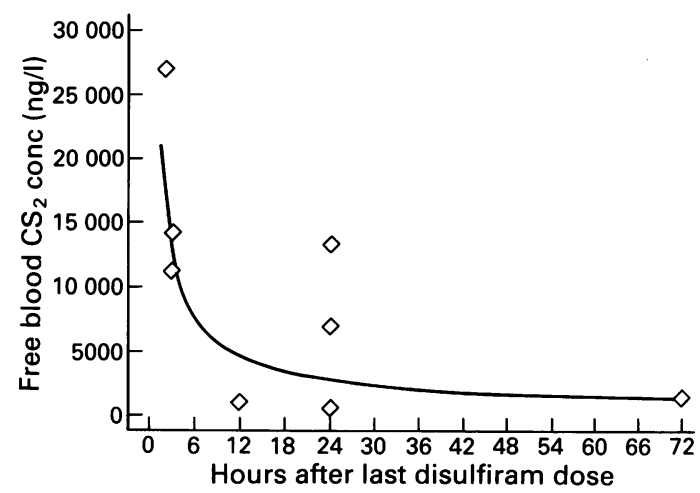

Figure 5 Correlation between free $C S_{2}(y)$ and time interval $(x)$ after the last administration of disulfiram $\left(y=\log 10.206 \times{ }^{\wedge-0.710} ; r=-0.640 ; n=8 ; N S\right)$.

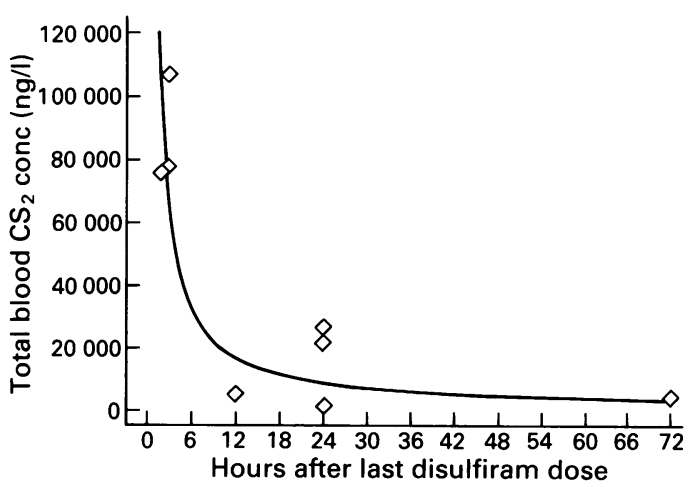

Figure 6 Correlation between total $\mathrm{CS}_{2}$ and interval after the last administration of disulfiram $(y=\log$ $\left.12.049 \times{ }^{\wedge-0.927} ; r=0.764 ; n=8 ; p<0.05\right)$.

$300^{\circ} \mathrm{C}$. With the detectable limit of our method equal to $25 \mathrm{ng} / \mathrm{l}$, it was possible to detect blood concentrations of $\mathrm{CS}_{2}$ in "normal" people (group A) within the following range (table 1): free $\mathrm{CS}_{2}$ from $37 \mathrm{ng} / \mathrm{l}$ to 758 $\mathrm{ng} / 1$ and total $\mathrm{CS}_{2}$ from $144 \mathrm{ng} / 1$ to $3095 \mathrm{ng} / 1$.

To verify the validity of our methods, especially at maximum blood concentrations, we tested blood samples from alcoholic subjects treated with disulfiram (Antabuse). Metabolism of this compound, as for all dithiocarbamates, produces $\mathrm{CS}_{2}$. Data in table 1 show that after the 19-38 days of treatment with disulfiram, the mean concentration of free $\mathrm{CS}_{2}$ was $9482 \mathrm{ng} / \mathrm{l}$ (about 35 times that for normal subjects $(261 \mathrm{ng} / \mathrm{l})$ ) and the mean value of total $\mathrm{CS}_{2}$ was 40084

Table 2 Correlations between free $C S_{2}(x)$ and total $C S_{2}(y)$ 


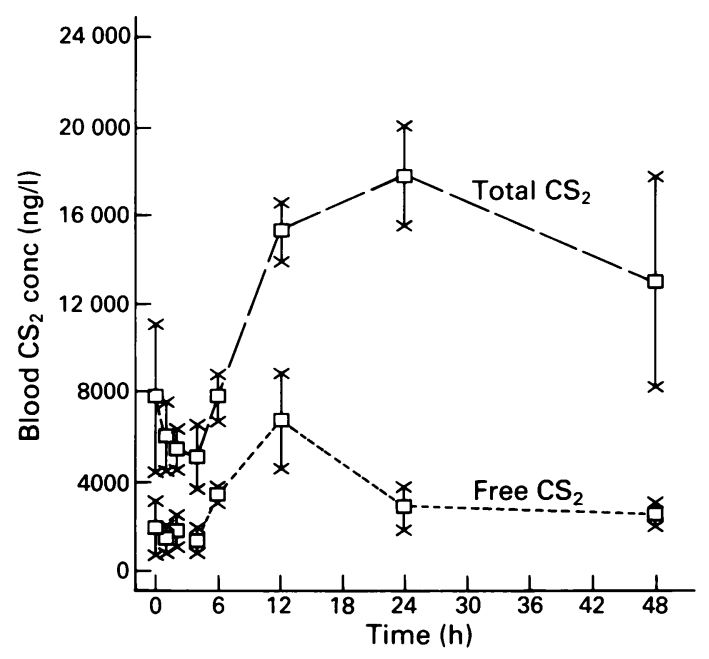

Figure 7 Variations of free and total $\mathrm{CS}_{2}$ concentration in the blood of three subjects after one single dose (200 $\mathrm{mg}$ ) of disulfiram.

$\mathrm{ng} / \mathrm{l}$ (about 50 times that for normal subjects ( 897 $\mathrm{ng} / \mathrm{l})$ ). Moreover, fig 7 shows that free $\mathrm{CS}_{2}$ concentration 12 hours after one single dose of disulfiram, reached about $6500 \mathrm{ng} / \mathrm{l}$, and the total $\mathrm{CS}_{2}$, after 24 hours, about $18000 \mathrm{ng} / \mathrm{l}$. The ratio between total and free $\mathrm{CS}_{2}$ was not related to the concentrations. Total $\mathrm{CS}_{2}$ was about four times higher than free $\mathrm{CS}_{2}$ in both normal (total:free $\mathrm{CS}_{2}=3.9$ ) and alcoholic (total:free $\mathrm{CS}_{2}=4.3$ ) subjects. A similar ratio for bound:free $\mathrm{CS}_{2}$ (3) was also found in animals after inhalation of $\mathrm{CS}_{2}{ }^{11}$ Free and total $\mathrm{CS}_{2}$ concentrations correlated with each other (table 2), both in groups $A$ and $B$ and in the two groups considered together.

The higher blood $\mathrm{CS}_{2}$ values found in alcoholic subjects (group B) were not significantly related to the duration of treatment (total disulfiram dosage), but were inversely proportional to the interval between the last administration of disulfiram and the time at which the blood sample was taken (figs 5 and 6). The blood half life of $\mathrm{CS}_{2}$ in the first 24 hours after administration of disulfiram was 10.6 hours for free $\mathrm{CS}_{2}$ and 6.9 hours for total $\mathrm{CS}_{2}$. In the 72 hours after the end of the treatment with disulfiram, half life of $\mathrm{CS}_{2}$ was $22 \cdot 8$ and $17 \cdot 3$ hours respectively for free and total $\mathrm{CS}_{2}$. The half life values we found are close to those calculated in alcoholic subjects treated with Antabuse. ${ }^{15}$ Analysis of expired air collected from these subjects, treated orally with $500 \mathrm{mg}$ disulfiram, indicated a half life of free $\mathrm{CS}_{2}$ of about 11 hours.

On the basis of our data it seems reasonable to suggest that the method presented here can be of use in evaluating occupational exposure to $\mathrm{CS}_{2}$. Biological monitoring by assaying blood $\mathrm{CS}_{2}$ concentrations in occupationally exposed subjects could confirm the validity of this approach. The appearance of high concentrations of $\mathrm{CS}_{2}$ after the administration of disulfiram, moreover, suggests that our method could be suited in the biological monitoring of exposure to dithiocarbamates.

This work was in part supported by the Italian National Research Council (CNR) targeted project: "Prevention and control of disease factors," subproject SP2: "Environmental quality and healthtoxicological methods for pesticide (grant No 91.00095 PF41).

Requests for reprints to: Professor Francesco Brugnone, Istituto di Medicina del Lavoro dell' Università di Verona, Policlinico Borgo Roma, 37134 Verona, Italy.

1 Lovelock JE. Carbon disulphide and the natural sulphur cycle. Nature 1974;248:625-6.

2 Aneja VP, Overton JH, Cupitt LT, Durhan JL, Wilson WE. Carbon disulphide and carbonyl sulphide from biogenic sources and their contributions to the global sulphur cycle. Nature 1979;282:493-6.

3 Bandy AR, Maroulis PJ. Impact of recent measurements of carbonyl sulfide, carbon disulfide and sulfur dioxide in background air on the global sulfur cycle. Proc Life Sci. 2nd Symposium. Proceedings of the Life Sciences, 1980;55:155.

4 Rasmussen RA, Khalil AK, Dalluge RW, Penkett SA, Jones B. Carbonyl sulfide and carbon disulfide from the eruption of Mount St Helens. Science 1982;215:665-7.

5 Beachamp RO Jr, Bus JS, Popp JA, Boreiko CJ, Goldberg L. A critical review of the literature on carbon disulfide toxicity. CRC Critical Reviews in Toxicology 1983;11:169-278.

6 Teisinger J. Biological exposure tests. Pure and Applied Chemistry 1961;3:253-7.

7 Milic S. Some observations concerning the determination of carbon disulfide in the urine of exposed workers. Proceedings of Yugoslavian symposium on carbon disulfide, Loznica 1965; 41:77.

8 Djuric D. Determination of carbon disulfide and its metabolites in biological material. In: Brieger $\mathrm{H}$, ed. Toxicology of carbon disulphide. Amsterdam: Excerpta Medica Foundation 1967; 52:51.

9 Lam C-W, Distefano V. Characterization of carbon disulfide binding in blood and other biological substances. Toxicol Appl Pharmacol 1986;86:235-42.

10 Lam C-W, Distefano V. Behavior and characterization of blood carbon disulfide in rats after inhalation. Toxicol Appl Pharmacol 1982;64:327-34.

11 Lam C-W, Distefano V. Blood-bound carbon disulfide: An indicator of carbon disulfide exposure, and its accumulation in repeatedly exposed rats. Toxicol Appl Pharmacol 1983;70: 402-40.

12 Lam C-W, Distefano V, Morken DA. The role of the red blood cell in the transport of carbon disulfide. J Appl Toxicol 1986;6:87-90.

13 Bartonicek V. The distribution of carbon disulfide in whole blood, the brain and the suprarenal gland over a given period in parenteral administration in white mice. Prac Lek 1957; 9:28-30.

14 Campbell L, Jones AH, Wilson HK. Evaluation of occupational exposure to carbon disulfide by blood, exhaled air and urine analysis. Am J Ind Med 1985;8:143-53.

15 Merlevede E, Casier H. Teneur en sulfure de carbone da l'air espire chez des personnes normales ou sous l'influence de l'alcool éthylique au cours du trattement par l'antabuse (disulfiram) et le diéthyldithiocarbammate de soude. Arch Int Pharmacodyn Ther 1961;132:427-53.

Accepted 9 December 1991 